\title{
ALIMENTOS GRAVÍDICOS: ASPECTOS POLÊMICOS
}

PREGNANCY ALIMONY: CONTROVERSIAL ASPECTS

Maria Isabel Ferreira MARQUES ${ }^{1}$

ISSUE DOI: $10.21207 / 1983.4225 .707$

\begin{abstract}
RESUMO
Os alimentos são essenciais para a manutenção da vida humana, motivo pelo qual as leis continuamente evoluíram no sentido de garantir ao máximo a efetividade desse direito. Ocorre que, por muito tempo, houve uma parcela da sociedade que esteve esquecida pelo legislador: as gestantes que não possuíam companheiro ou cônjuge. Somente em 2008, com a edição da Lei $\mathrm{n}^{\circ} 11.804$, é que se dispôs expressamente sobre o direito a alimentos gravídicos. Desde então, foi possível uma maior proteção a essas mulheres com especial condição e, por conseguinte, restaram resguardados os direitos daquele que estava por nascer. Afinal, considerando que há incontroversa relação entre a gestação saudável da mulher e o nascimento digno da criança, é possível se afirmar que o nascituro, mesmo que de forma consequente, foi abrangido por esse diploma normativo. Dessa forma, embora tenham sido mais expressivas as críticas do que os elogios, a lei vem se mostrando merecedora de enaltecimento, em razão de seu propósito tão salutar. As discussões acerca do tema, por sua vez, têm sido de extrema valia para a quebra de normas que não mais se coadunam com os valores contemporâneos, bem como têm sido úteis para a ampla divulgação de um direito que, por vezes, permanece desconhecido por muitas mulheres. Portanto, os alimentos gravídicos representam tema atual e de extrema relevância, aos quais deve ser destinado maior espaço para debate.
\end{abstract}

Palavras-chave: alimentos gravídicos; concepção; nascituro; direito fundamental; gestante.

\section{ABSTRACT}

Alimony is essential for the maintenance of human life, being the reason that the laws have continuously evolved, guaranteeing the maximum effectiveness of this right. It occurs that, for a long period of time,

1 Graduada em Direito pela Universidade Paulista (UNIP). Advogada. http://lattes.cnpq.br/3511356265321506 . 
there was a part of society that had been forgotten by the legislator: the pregnant women who had not a partner or husband. Only in 2008, with the enactment of Law $n^{\circ} 11,804$, the right to the pregnancy alimony became specifically provided for. Since then, it has been possible to provide more protection to these women with special status and, therefore, the rights of the unborn have been preserved. After all, considering that there is an uncontroversial relationship between the healthy gestation of the woman and the decent birth of a child, it is possible to affirm that the unborn child, even if consequently, was protected by such a normative ruling. Thus, although criticisms have been more expressive than praises, the law has shown itself worthy of praise because of its salutary purposes. On the other hand, the arguments concerning this subject have been extremely useful for the breaking of norms that are no longer compatible with contemporary values, in addition, they have been useful for the wide dissemination of a right that is sometimes unknown by many women. Therefore, pregnancy alimony represents a current topic of extreme relevance, which should be given more space for debate.

Keywords: pregnancy alimony; conception; unborn child; fundamental right; pregnant.

\section{$1 \quad$ INTRODUÇÃO}

\subsection{APRESENTAÇÃO DO TEMA}

Os alimentos gravídicos já eram concedidos antes da Lei $\mathrm{n}^{\circ}$ 11.804, de 2008, (Lei de Alimentos Gravídicos) que não prejudicou as ações em andamento ${ }^{2}$, mas, decerto, sem legislação própria, era matéria turva no âmbito jurídico.

Assim, sancionado o projeto que deu origem à lei de 2008, essa espécie de alimentos passou a ser expressamente regulada por uma lei própria, em consonância com os princípios da dignidade da pessoa humana e da paternidade responsável.

No entanto, ainda há óbices ao reconhecimento desse direito, por se tratar de assunto hodierno, e tendo em vista as peculiaridades trazidas pela lei. Foram seis os artigos vetados, de um total de doze, fato que, inquestionavelmente, contribui para a insegurança inerente ao tema, cujo regramento legal parece, por vezes, mais criar lacunas do que preencher aquelas existentes.

\footnotetext{
${ }^{2}$ Família - Gravidez - Alimentos - Antes da Lei no 11.804/2008 - Possibilidade de aplicação da lei em ação ajuizada anteriormente à vigência da referida lei - Atuais alimentos gravídicos. - "Em processos distribuídos anteriormente a Lei ${ }^{\circ} 11.804 / 08$, porém, ainda em tramitação e até, neste caso concreto, sem citação, ainda não estabelecida a relação processual, em que a autora grávida pleiteia alimentos, poderá o pedido ser apreciado e aceito; vez que a lei não estará retroagindo, não havendo que se falar em impossibilidade jurídica do pedido, pelo único motivo da ação ter sido ajuizada antes da vigência da referida Lei. A moderna concepção de processo, sustentada pelos princípios da economia, instrumentalidade e celeridade processual, determina o aproveitamento máximo dos atos processuais, principalmente quando se trata de ação de cunho alimentar e quando não há prejuízo para a defesa das partes." (TJ-MG 107020849950840011 MG 1.0702.08.499508-4/001(1), Rel. Des. Geraldo Augusto, j. 26/05/2009). (grifou-se)
} 
Apenas como exemplo, ao contrário do que prescreve a Lei $\mathrm{n}^{\circ}$ 5.478, de 1968, (Lei de Alimentos), não se exige prova robusta de paternidade para a fixação dos alimentos gravídicos, bastando que o juiz se convença da existência de indícios de paternidade. A Lei de Alimentos Gravídicos inova, dessa forma, em seu artigo $6^{\circ}$, quando trata dos denominados indícios de paternidade, ao tempo em que sequer explica no que consistem.

Outras questões controversas acabam, igualmente, por mistificar o assunto, a exemplo, também, da conversão automática prevista no parágrafo único, do artigo $6^{\circ}$, pela qual os alimentos gravídicos se convertem em pensão alimentícia para a criança, após o nascimento, o que perdura até eventual pedido de revisão.

Ainda, da mesma forma que a legislação nunca definiu, em termos claros, o que se entende por alimentos, a Lei de Alimentos Gravídicos seguiu a mesma tendência ao não conceituá-los. Apesar disso, apontou, em seu artigo $2^{\circ}$, a abrangência deles:

\footnotetext{
“ [...] valores suficientes para cobrir as despesas adicionais do período de gravidez e que sejam dela decorrentes, da concepção ao parto, inclusive as referentes a alimentação especial, assistência médica e psicológica, exames complementares, internações, parto, medicamentos e demais prescrições preventivas e terapêuticas indispensáveis, a juízo do médico, além de outras que o juiz considere pertinentes."
}

Logo, nota-se que, não obstante sejam indicadas quais despesas os alimentos gravídicos compreendem, o texto dá margem para a inclusão de outras não especificamente citadas. Afinal, deve ter se pensado ser impossível estabelecer todas as despesas adicionais do período de gravidez. Por isso o rol meramente exemplificativo.

Além do mais, o artigo assinala, de forma clara, que o julgador pode fazer seu próprio juízo de valor sobre outros gastos que lhe parecerem pertinentes, o que alarga ainda mais as possibilidades. Porém, não se questiona que o valor a ser fixado deva se ater às despesas decorrentes apenas da gravidez, e não as particulares da gestante.

Destarte, é possível que se estabeleça um conceito para alimentos gravídicos, aliado ao texto legal, à doutrina majoritária e ao próprio conceito de alimentos. E o que se entende é que se trata de uma espécie de alimentos devida pelo futuro pai, visando ao amparo da mulher por meio do pagamento de subsídios gestacionais, os quais devem ser fixados 
proporcionalmente aos recursos de ambos (artigo $2^{\circ}$, parágrafo único, Lei $n^{\circ} 11.804$, de 2008).

Deste modo, a lei pode ser vista como uma inovação benéfica no ordenamento jurídico brasileiro, pois introduz a ideia de que, se existe obrigação alimentar durante a gestação, seu termo inicial é a concepção. Não bastasse, demonstra dedicação do legislador à matéria essencial para a dignidade da pessoa humana e para a especial proteção das famílias, tão almejada pela Constituição.

Nesse sentido, discorreu Maria Berenice Dias, em seu artigo "Alimentos Gravídicos?":

\footnotetext{
"Claro que as leis não despertam a consciência do dever, mas geram responsabilidades, o que é um bom começo para quem nasce. Mesmo sendo fruto de uma relação desfeita, ainda assim o filho terá a certeza de que foi amparado por seus pais desde que foi concebido, o que já é uma garantia de respeito à sua dignidade."
}

\subsection{CONCEITO DE ALIMENTOS}

O Estado tem o dever precípuo de garantir a vida. Não apenas ela, mas também a sobrevivência digna do ser humano. É o que estabelece o artigo $1^{\circ}$, III, da Constituição Federal, quando indica os fundamentos da República Federativa do Brasil enquanto Estado Democrático de Direito.

Em seu artigo $5^{\circ}$, encontra-se garantida a inviolabilidade da vida, da qual decorre um imenso rol de direitos e de garantias fundamentais. E, no artigo $6^{\circ}$, estão os direitos sociais, entre os quais se inserem a saúde, a alimentação, a moradia, a proteção à maternidade etc.

É do Estado, portanto, a obrigação de regulamentar a prestação alimentícia e, haja vista que ela está intimamente ligada à sobrevivência de alguém, foram criados meios singulares para assegurá-la, como a norma do artigo $5^{\circ}$, LXVII, da Carta Magna, que possibilita a prisão civil do alimentante, destacando-se o fato de que esta é, atualmente, a única espécie de prisão civil remanescente em nosso ordenamento jurídico. ${ }^{3} \mathrm{O}$ artigo 100,

\footnotetext{
${ }^{3}$ V Jornada de Direito Civil, 522. “Arts. 1.694, 1.696, primeira parte, e 1.706: Cabe prisão civil do devedor nos casos de não prestação de alimentos gravídicos estabelecidos com base na Lei $\mathrm{n}$. 11.804/2008, inclusive deferidos em qualquer caso de tutela de urgência."
} 
caput e $\S 1^{\circ}$, a seu turno, garante um privilégio constitucional aos débitos de natureza alimentícia: eles gozam de preferência sobre os demais. ${ }^{4}$

Seguindo a mesma lógica, os preceitos dos artigos 53, II, 215, II, e 528 e seguintes, todos do Código de Processo Civil, que asseguram, respectivamente, privilégio, nas ações, do foro do domicílio ou da residência do alimentando, regra especial de tramitação processual e garantias especiais de execução.

E, anteriormente a todos os dispositivos neste item citados, já havia a Lei de Alimentos - Lei $\mathrm{n}^{\circ}$ 5.478, de 1968 -, que dispõe sobre múltiplos aspectos da ação alimentícia (rito processual, provas, citação etc.).

Nela, instituiu-se rito especial para a ação e, justamente por ter como fundamento a garantia da sobrevivência de uma pessoa, esse rito prevalece nas demais ações que são cumuladas com a de alimentos. Inverteu-se o encargo probatório: como dito, o credor prova o vínculo jurídico, enquanto o devedor faz a demonstração de seus rendimentos (exceto quando se tratar de filhos maiores, cônjuges e netos). Com o advento do Código de Processo Civil, de 2015, no entanto, o procedimento executório previsto na aludida lei foi revogado.

Apenas muitos anos depois, editou-se a Lei de Alimentos Gravídicos - Lei n ${ }^{\circ} 11.804$, de 2008 -, originada no Projeto de Lei nº 7.376B, de 2006.

Importante, dessa forma, que ao menos se tente conceituar alimentos a partir de concepções doutrinárias, tendo em vista a falta de previsão expressa no Código Civil, que somente veio a definir legado de alimentos enquanto aquele que abrange necessidades básicas, como o sustento, a cura e o vestuário (artigo 1.920).

A Constituição, semelhantemente, não os conceitua, mas oferece parâmetros para tanto, como quando prevê, no artigo 229, o dever dos pais de assistir, criar e educar os filhos menores, bem como o dever dos filhos maiores de amparar os pais na velhice, carência ou enfermidade.

Assim, dentre muitas definições que, no geral, não divergem entre si e associam alimentos a tudo que se preste a prover a subsistência de quem está impossibilitado de fazê-lo, é bem acertada aquela concebida por Yussef Said Cahali, em sua obra "Dos Alimentos", quando enuncia:

\footnotetext{
${ }^{4}$ NERY, Rosa Maria de Andrade Nery. Manual de direito civil: família. 1. ed. São Paulo: Editora Revista dos Tribunais, 2013, p. 375.
} 
“Adotada no direito para designar o conteúdo de uma pretensão ou
de uma obrigação, a palavra ‘alimentos’ vem a significar tudo o que
é necessário para satisfazer aos reclamos da vida; são as prestações
com as quais podem ser satisfeitas as necessidades vitais de quem
não pode provê-las por si; mais amplamente, é a contribuição
periódica assegurada a alguém por um título de direito, para exigi-
la de outrem, como necessário à sua manutenção.”

E a partir dessa definição, cumpre consignar que a doutrina comumente diferencia o sentido comum do sentido jurídico do termo alimentos. No primeiro, comum, é limitado a tudo o que é necessário para o sustento de uma pessoa. Já no segundo, jurídico, é mais ampla a abrangência, consistindo não apenas no indispensável ao sustento, mas também nas demais necessidades essenciais para a manutenção da condição social e moral daquele que os pleiteia.

Essa distinção coincide com aquela feita entre os alimentos naturais e os civis: os naturais, ou necessários, se restringem ao suprimento de necessidades básicas e indispensáveis, como alimentação, saúde, vestuário, moradia; os civis, ou côngruos, alcançam necessidades relativas à vida social do alimentando.

Outro ponto omisso no Código Civil é o não estabelecimento da natureza do direito à prestação de alimentos, motivo pelo qual foram formadas três correntes doutrinárias. A primeira se posiciona no sentido de que os alimentos representam um direito extrapatrimonial, pelo fato de atenderem a um interesse de ordem superior e familiar; afinal, eles não integram o patrimônio do alimentando, sequer podendo servir como garantia a eventuais credores, razão pela qual não seriam dotados de caráter patrimonial. A segunda corrente, por sua vez, entende que se trata de direito patrimonial, sob o argumento de que o direito a alimentos se efetiva por meio de prestações econômicas exigíveis de um devedor em favor de um credor, o que caracterizaria uma relação obrigacional. Por fim, a terceira corrente é aquela que defende uma natureza mista, uma vez que estariam presentes tanto o aspecto pessoal quanto o patrimonial.

No entanto, prepondera a última corrente, de forma que os alimentos podem ser definidos como um direito de conteúdo patrimonial e de finalidade pessoal. ${ }^{5}$

De qualquer forma, é incontroverso que, quando se discute alimentos, há que se invocar o princípio basilar previsto no $\S 1^{\circ}$, do artigo

\footnotetext{
${ }^{5}$ GONÇALVES, Carlos Roberto. Direito civil brasileiro, v. 6: direito de família. 9. ed. São Paulo: Saraiva, 2012, p. 500.
} 
1.694, do Código Civil, o qual estipula que "os alimentos devem ser fixados na proporção das necessidades do reclamante e dos recursos da pessoa obrigada". No mesmo sentido é o artigo 1.695 desse texto legal.

Trata-se do chamado binômio necessidade-possiblidade, consistente em um pressuposto que condiciona a obrigação alimentar. Sem a necessidade ou a possibilidade, deixa de existir o encargo. Entretanto, uma vez presente o binômio, ele deve ser usado como base para a estipulação do valor a ser fixado.

Em outras palavras, o juiz deve analisar, cautelosa e simultaneamente, tanto a necessidade daquele que pede a pensão quanto a possibilidade daquele para quem se pede. Isso porque, evidentemente, de nada adianta que eles sejam estipulados para suprir a carência do alimentando se o alimentante não tiver condições de adimpli-los.

Se assim não fosse, ocorreria o que alguns chamam de partilha de misérias, isto é, para ajudar aquele que está em situação de penúria, impor-se-ia ao outro, que dispõe de modestos rendimentos, um encargo que não está em condições de suportar. ${ }^{6}$

Cumpre registrar apenas que, tratando-se de alimentos, o principal é provar o vínculo jurídico entre o credor e o devedor. Mesmo os chamados provisórios - fixados liminarmente - exigem prova préconstituída para a sua concessão. Tal regra, no entanto, se encontra excetuada pelos alimentos gravídicos, os quais se baseiam em indícios de verossimilhança da existência desse vínculo.

Há, ainda, aqueles que sustentam existir, na realidade, um trinômio, porquanto, além da necessidade e da possibilidade, é preciso haver proporcionalidade na fixação dos alimentos. Contudo, a desproporcionalidade, nesses casos, não desonera o devedor do pagamento, e sim permite-lhe ingressar com ação revisional, a qualquer tempo, para que o valor seja reajustado de acordo com sua verdadeira condição financeira. Além dessa hipótese, referida ação só poderá ser ajuizada com base em fatos posteriores à sentença que fixa alimentos, sem os quais não se pode modificar o seu valor.

Outro aspecto importante dos alimentos é o de que apenas parentes, cônjuges e companheiros podem pedi-los uns aos outros, de

${ }^{6}$ CAHALI, Yussef Said Cahali. Dos alimentos. 4. ed. São Paulo: Revista dos Tribunais, 2002, p. 724-725. 
forma que tal obrigação não atinge todo e qualquer cidadão, de acordo com o bel-prazer do requerente.

O Código Civil atende, de um lado, ao princípio da solidariedade familiar, quando alcança todos os laços de parentalidade e, de outro, ao princípio da isonomia, por não estabelecer distinção entre o casamento e a união estável. E a tendência, seguramente, é de que estejam abrangidas, nesse rol, as demais configurações familiares que vierem a existir, considerando que são os elos de afeto que dão origem às relações familiares $\mathrm{e}$, consequentemente, às obrigações delas decorrentes. ${ }^{7}$

Por fim, por estarem os alimentos estreitamente ligados à sobrevivência daqueles que os pleiteia, diz-se que eles são regidos por normas cogentes de ordem pública, as quais visam a atender ao interesse da coletividade.

Isso significa que, mesmo se tratando de acordo de alimentos, as partes estão proibidas de simplesmente derrogar ou modificar tais regras. A autonomia da vontade dos contratantes, em tais situações, deve se conformar aos limites impostos pelo legislador.

\subsection{CARACTERÍSTICAS}

Os alimentos possuem diversas características que, de regra, denotam seu caráter de imprescindibilidade para aquele que os pleiteia.

Primeiramente, por ser personalíssimo e indisponível, o direito alimentar é intransferível, não podendo ser objeto de cessão, compensação, penhora, alienação ou transação. Característica distinta, portanto, daquela atribuída à obrigação alimentar, a qual pode ser transmitida para os herdeiros, conforme disposição do artigo 1.700, do Código Civil. Assim, mesmo se sobrevier o óbito do alimentante, no curso da ação de alimentos, a demanda poderá prosseguir contra os seus sucessores (inclusive se for cumulada com investigação de paternidade). ${ }^{8}$

\footnotetext{
${ }^{7}$ Maria Berenice Dias, "Um Crédito de Amor".

${ }^{8}$ Ação de investigação de paternidade cumulada com pedido de alimentos. Investigado que faleceu antes da citação. Demanda que prossegue contra os sucessores do de cujus. Sentença que, diante do resultado do exame de DNA realizado após coleta de material hematológico do investigante e dos outros filhos do investigado nascidos em casamento anterior, julgou procedente o pedido para reconhecer a paternidade e fixar alimentos definitivos em $30 \%$ do valor recebido pela viúva a título de pensão do INSS. "Insurgência dos apelantes quanto ao reconhecimento da paternidade e à fixação de alimentos. Exame de DNA que aferiu 30 alelos que compõem a cadeia genética do autor, dos quais
} 
Não obstante seja vedada a disponibilidade e a renúncia do direito alimentar, é admitida convenção a respeito da fixação de alimentos (forma e dia de pagamento etc.), podendo, inclusive, ser a obrigação dividida entre eventuais devedores. Nesse sentido, o artigo 1.707, do Código Civil: "Pode o credor não exercer, porém lhe é vedado renunciar o direito a alimentos, sendo o respectivo crédito insuscetível de cessão, compensação ou penhora".

Isto posto, percebe-se que o não exercício do direito alimentar não significa renúncia por parte de seu titular. Admite-se a renúncia apenas no que concerne às prestações alimentares vencidas e não pagas, sendo, portanto, lícita a transação que visa a quitar a prestação de alimentos pretéritos não pagos ou pagos em quantia menor àquela devida. ${ }^{9}$

Outra característica importante é a imprescritibilidade, uma vez que tal direito pode ser postulado em juízo a qualquer tempo - isto é, ao menos enquanto se conservar o vínculo que a ele deu origem. Prescreve, todavia, a pretensão executória referente às prestações vencidas (artigo 206, § 2º Código Civil).

A irrepetibilidade, por sua vez, significa que os alimentos, uma vez pagos, não podem ser objeto de restituição. Tal regra subsiste mesmo que sejam concedidos em caráter provisório, ou então que a sentença venha a julgar improcedente a ação alimentar, e até mesmo na hipótese de o recurso modificar decisão anterior, alterando o montante a ser pago. Como bem ressaltou Carlos Roberto Gonçalves: "quem pagou alimentos, pagou uma dívida, não se tratando de simples antecipação ou de empréstimo". ${ }^{10}$

15 têm origem materna e 15 paterna. Comparação do material genético do investigante com o dos supostos irmãos que identificou os 15 loci extraídos da parte atribuída ao pai na cadeia genética dos filhos do de cujus. Prova testemunhal que corrobora a paternidade. Reforma da sentença no tocante à condenação dos apelantes ao pagamento de pensão alimentícia. Inexistência de obrigação alimentar constituída antes do falecimento do genitor do demandante a ser transmitida aos herdeiros do de cujus. Inaplicabilidade do disposto no art. 1.700 do código civil de 2002 ao caso concreto. Recurso parcialmente provido." (Apelação Cível n 18300 SC 2008.001830-0, 2a Câmara de Direito Civil do Tribunal de Justiça de Santa Catarina, Rel. Des. Nelson Schaefer Martins, j.26/11/2010). (grifou-se)

${ }^{9}$ Direito civil. Execução de alimentos. Acordo firmado entre as partes. Renúncia. Alimentos pretéritos. Possibilidade. "I - A irrenunciabilidade ao direito aos alimentos decorre de seu caráter de essencialidade à sobrevivência. No entanto, é firme o entendimento jurisprudencial de que em se tratando de alimentos pretéritos, considerando que a parte sobreviveu sem o seu pagamento, esta é portadora de um simples crédito, sendo possível transacionar a respeito do mesmo. II - As partes transacionaram somente quanto ao débito alimentar vencido, para o que inexiste óbice legal. Nesse contexto, não há razão para impor às partes integrantes da relação alimentar óbice ao ajuste, visto que deste não decorre prejuízo ao sustento dos alimentados. III - Negou-se provimento ao recurso." (Apelação Cível no 20100610125767, 6 a Turma Cível do Tribunal de Justiça do Distrito Federal, Rel. Des. José Divino de Oliveira, j. 16/09/2015). (grifou-se)

${ }^{10}$ Carlos Roberto Gonçalves, Direito civil brasileiro: direito de família, p. 523. 
Persiste, no entanto, exceção à regra da irrepetibilidade, tanto nos casos em que ocorre erro no pagamento dos alimentos (em duplicidade ou em excesso) quanto naqueles em que se configura má-fé por parte do autor da ação. Isso porque, em tais situações, entende-se ter ocorrido enriquecimento sem causa por parte do beneficiário do depósito do valor de alimentos, o que impõe o dever de restituição obrigatória ao depositante, conforme o artigo 884, do Código Civil. ${ }^{11}$

A atualidade é, também, um traço distintivo desse direito, devido ao fato de que os alimentos só podem ser exigidos em relação ao tempo presente, e devem ser fixados de acordo com o critério de correção vigente. Ainda que irrenunciáveis e que não exercidos, se pleiteados, os alimentos só passarão a ser devidos ad futurum. Não obstante, a obrigação é mutável consoante o binômio necessidade-possibilidade já aludido.

Por fim, há que se falar sobre a solidariedade, a proximidade e a reciprocidade.

A primeira (solidariedade) é aquela que obriga cônjuges, companheiros, pais, filhos e parentes, os quais, todavia, serão acionados segundo critérios de proporcionalidade (quem tem mais condições de arcar com o ônus) e de proximidade (recai sobre os mais próximos). Inclusive, se a obrigação não for individualizada, de forma a obrigar todos os devedores, será admitida ação de regresso

A terceira (reciprocidade), por sua vez, pode se verificar em duas situações diferentes. Existe, de um lado, o dever recíproco de assistência entre cônjuges, companheiros e parentes, o que leva à conclusão de que, a depender das condições pessoais de cada um, os papéis de credor e devedor podem se inverter para atender às necessidades pertinentes àquele momento específico. De outro lado, existe a reciprocidade que passa a existir com a cessação do poder familiar, no momento em que os filhos

\footnotetext{
${ }^{11}$ Direito civil e processual civil. Execução de alimentos. Comprovado pagamento de alimentos em excesso ao que havia sido acordado em juízo diante de ordem de prisão determinada pelo juízo a quo. Pagamento em duplicidade e em excesso. Pedido de compensação e restituição. Circunstâncias excepcionais comprovadas. Recurso provido. "1 - O depósito de significativa importância a maior na conta corrente bancária da genitora da exequiente restou comprovado nos autos através de reconhecimento expresso feito pela apelada, por meio de petição juntada aos autos. 2 - Os valores pagos a título de alimentos, quando a maior, ainda que depositados em conta corrente de terceiros, não são, em regra, repetíveis nem compensáveis. Excepciona-se dessa regra a hipótese em que exista nos autos prova irrefutável do excesso, o excesso não represente importância insignificante e o excesso não tenha resultado de simples liberalidade do devedor de alimentos, caso em que sua não restituição representará inequívoco enriquecimento sem causa do beneficiário do depósito, enriquecimento esse que é vedado por nosso direito. 3 - Apelo provido." (Apelação Cível no 20050610094059, $5^{\mathrm{a}}$ Turma Cível do,Tribunal de Justiça do Distrito Federal, Rel. Des. Esdras Neves, j. 11/04/2007). (grifou-se)
} 
atingem a maioridade e podem figurar como devedores de alimentos aos seus genitores.

\section{ALIMENTOS GRAVÍDICOS E SEUS ASPECTOS}

\section{$2.1 \quad$ LEGITIMIDADE PROCESSUAL}

\subsubsection{LEGITIMIDADE ATIVA}

Não há dúvidas: a legitimidade ativa da ação de alimentos gravídicos é da mulher gestante. Embora se reconheça que esse é um tópico de elevada controvérsia, parece nítido, ao mesmo tempo, que a Lei $\mathrm{n}^{\circ}$ 11.804 , de 2008, tenha conferido à gestante - e a ninguém mais - o direito de pedir essa espécie de alimentos.

Para os que defendem essa corrente, tem-se como principal fundamento o artigo $1^{\circ}$, da referida lei. ${ }^{12}$ A princípio, porque eles se destinam a custear despesas provenientes da gravidez, mas não em sua totalidade. O parágrafo único do artigo $2^{\circ}$ é categórico ao preceituar que parte das despesas deve ser paga pelo futuro pai, e parte pela mulher grávida, na proporção de seus respectivos recursos.

Logo, objetivam suprir a necessidade da mulher grávida, propriamente em razão de sua especial condição. Inclusive porque não são poucas as despesas. Desde um simples teste de gravidez até a preparação do enxoval, é considerável a variedade de gastos possíveis. Por isso mesmo a lei optou por não enumerar minuciosamente quais despesas deveriam ou não integrar os alimentos gravídicos, sendo fundamental a apreciação do médico e do juiz, em cada caso, para se definir o que é pertinente ser cobrado.

Outro argumento que se tem a favor da legitimidade ativa da gestante é o fato de que a lei sugere que apenas aquelas não casadas ou que não convivam em união estável é que poderiam ingressar com essa ação.

\footnotetext{
${ }^{12}$ Lei $\mathrm{n}^{\mathrm{o}} 11.804$, de 2008 , artigo $1^{\circ}$. "Esta Lei disciplina o direito de alimentos da mulher gestante e a forma como será exercido."
} 
Em que pese ter sido o texto normativo omisso sobre essa questão, é perfeitamente aceitável o entendimento de que apenas a grávida que não mais convive com o futuro pai de seu filho terá referida legitimidade. Ora, se ainda estivesse em sua companhia, supor-se-ia que os alimentos seriam pagos in natura, ou melhor, nas despesas diárias decorrentes da convivência doméstica.

Contudo, o dispositivo em análise parece ter ido além: não alcança só gestantes separadas ou divorciadas, mas também - e especialmente - aquelas que não possuem qualquer vínculo com o futuro pai, sendo a gravidez fruto de um relacionamento fugaz, o qual, sem embargo, não deve restar desamparado.

E diz-se que foram abrangidas especialmente essas mulheres porque, pela primeira vez, foram levadas em consideração quando da elaboração de uma lei, sendo que companheiros ou cônjuges separados já podiam se valer do artigo 1.694, do Código Civil, para elaborar pedido de alimentos.

Trata-se, ainda, indiretamente, de um reforço da vedação às regras discriminatórias de filiação. Isso porque somente com o advento da Constituição Federal de 1988 é que foram proibidas distinções legais entre os chamados filhos legítimos e ilegítimos.

Assim, em última análise, o que se pretendia com esse dispositivo - artigo $1^{\circ}$, da Lei $n^{\circ} 11.804$, de 2008 - era precisamente legitimar a mulher grávida a buscar alimentos do futuro pai, independentemente de possuir algum vínculo afetivo com ele. Até então, o que mais comumente ocorria era o pagamento de alimentos somente após a criança nascer. Dessa forma, restavam negligenciadas as necessidades da gestante que tinha que custear, sozinha, sua gravidez.

Mesmo que reconhecido o direito ao reembolso, a crítica é no sentido de que não se pode sobrepor a resistência do futuro genitor de cumprir a sua obrigação à necessidade de sobrevivência da gestante. Afinal, não tinha apenas a mulher que custear sua gravidez sem ajuda do futuro pai, mas também ter que fazê-lo na condição de grávida.

Contudo, há quem sustente que os alimentos gravídicos se tratariam, na realidade, de alimentos do ventre ou do nascituro. ${ }^{13}$

\footnotetext{
${ }^{13}$ Jones Figueirêdo Alves, “Alimentos do Ventre”.
} 
Sob alegação de que possuem base nos direitos do nascituro, há uma corrente que defende que o verdadeiro autor da ação de alimentos deveria ser o nascituro. Tendo em vista que o artigo $2^{\circ}$, do Código Civil, já resguardou os direitos daquele concebido (apenas a título de exemplo: o artigo 1.609, parágrafo único, do Código Civil, que permite o reconhecimento de paternidade antes do nascimento do filho, e os artigos 542, 1.779 e 1.798, do Código Civil, que dispõem sobre o direito do nascituro de receber doação, herança e de ser curatelado), defende-se que os alimentos gravídicos seriam devidos ao filho, e tão somente auferidos pela gestante. Esta, por sua vez, exerceria uma espécie de legitimidade extraordinária.

E, realmente, já houve decisão precursora nesse sentido, durante o trâmite da apelação cível $n^{\circ} 193.648-1$, julgada em 14/09/1993, pela $1^{\text {a }}$ Câmara do Tribunal de Justiça de São Paulo, em que se atribuiu legitimidade ad causam ao nascituro, representado pela mãe, uma vez que ele possuiria expectativa de direito resguardada.

Nota-se, todavia, que é mais sensata a primeira corrente, segundo a qual cabe à gestante ingressar com a ação, pois é ela a detentora do direito a alimentos. E por ser essa a perspectiva mais garantidora da dignidade da pessoa humana, é a que deve prevalecer. Reconhecê-la assim vai ao encontro da almejada proteção à maternidade e, consequentemente, do nascimento digno da criança.

Assim, o posicionamento do Superior Tribunal de Justiça, quando do julgamento do Recurso Especial no 1.629.423-SP (Rel. Ministro Marco Aurélio Bellizze, j. 06/06/2017, v.u.):

\footnotetext{
"Os alimentos gravídicos, previstos na Lei n. 11.804/2008, visam auxiliar a mulher gestante nas despesas decorrentes da gravidez, da concepção ao parto, sendo, pois, a gestante a beneficiária direta dos alimentos gravídicos, ficando, por via de consequência, resguardados os direitos do próprio nascituro." (grifou-se)
}

Por fim, cumpre consignar que o artigo 24, da Lei de Alimentos, prevê a possibilidade de ajuizamento de ação de oferta de alimentos, na qual o alimentante vem a juízo se dispor ao seu pagamento. Nesse caso, é feita a citação do alimentando para que compareça à audiência de conciliação, na qual poderá ser realizada transação. Não havendo acordo, a prestação será fixada por decisão judicial.

Não se vislumbra qualquer impedimento para a aplicação do referido dispositivo no âmbito dos alimentos gravídicos, os quais também 
poderiam ser ofertados por meio de ação própria. Afinal, se a Lei de Alimentos Gravídicos não dispôs de modo contrário, e considerando que o ajuizamento da ação demonstra o interesse do devedor no cumprimento da obrigação, é lícito concluir pela possibilidade da legitimidade ativa do provável pai em ação de oferta de alimentos gravídicos.

Indubitavelmente, nas ações de oferta de alimentos, no geral, tem-se como maior interessado aquele que receberá os alimentos, porquanto terá, mais facilmente, efetivado seu direito. No entanto, deve-se lembrar que, para o autor dessa demanda, não apenas existe pretensão de prover à subsistência do alimentando, mesmo que parcialmente (visando a impedir que este acabe relegado ao infortúnio), como também a intenção de evitar que contra ele seja ajuizada ação de alimentos, vindo a pensão provisória a ser fixada em valor acima de suas possibilidades (razão pela qual prefere se antecipar demonstrando seus ganhos).

\subsubsection{LEGITIMIDADE PASSIVA}

No que diz respeito à legitimidade passiva, indiscutível ser ela do futuro pai. A discussão, nesse ponto, reside unicamente na exigibilidade dessa obrigação quanto aos futuros avós. E o que se entende é que, de um lado, por ausência de previsão legal específica, descaberia a inclusão dos avós no polo passivo da demanda. Por outro, já há quem fale em alimentos gravídicos avoengos. ${ }^{14}$

Sob a ótica da proteção da maternidade e em razão da relação de parentesco, entende-se serem exigíveis os alimentos também dos avós. A lei até pode ter sido omissa quanto a essa possibilidade, mas certamente não dispôs em sentido contrário, o que mais viabiliza a aplicação supletiva de outros textos legais.

Assim, o Código Civil já determina que a obrigação alimentar pode recair sobre ascendentes de grau mais próximo. ${ }^{15} \mathrm{E}$ o que permite a aplicação desse dispositivo é a demonstração de que o devedor está

\footnotetext{
${ }^{14}$ Leandro Soares Lomeu, "Alimentos Gravídicos Avoengos".

${ }^{15}$ Art. 1.696. "O direito à prestação de alimentos é recíproco entre pais e filhos, e extensivo a todos os ascendentes, recaindo a obrigação nos mais próximos em grau, uns em falta de outros."

Art. 1.698. "Se o parente, que deve alimentos em primeiro lugar, não estiver em condições de suportar totalmente o encargo, serão chamados a concorrer os de grau imediato; sendo várias as pessoas obrigadas a prestar alimentos, todas devem concorrer na proporção dos respectivos recursos, e, intentada ação contra uma delas, poderão as demais ser chamadas a integrar a lide.”
} 
totalmente impossibilitado de cumprir sua obrigação. Cabe ao autor da demanda o ônus da prova dessa condição do réu, tratando-se de matéria de mérito a ser apreciada durante a instrução processual. ${ }^{16}$

Na prática, podem ocorrer as seguintes situações: $a$ ) a ação de alimentos é intentada contra o devedor e, ao longo do processo, verifica-se que ele não reúne condições para arcar sozinho com a obrigação (neste caso, é permitida a inclusão tardia de seus genitores - avós do autor - no polo passivo da demanda ${ }^{17}$; $b$ ) já se sabe, de antemão, que o devedor não está apto a responder pela obrigação (logo, a ação pode ser intentada somente contra seus genitores).

Em ambos os casos, os avós podem ser chamados para complementar o valor, e não apenas para pagá-lo integralmente. ${ }^{18}$ Porém, por se tratar de responsabilidade subsidiária e complementar (e não solidária), em ambos os casos ocorrerá a exclusão dos avós da lide se restar provado que o pai possui condições de sustento.

Destarte, nada mais lógico que a viabilidade da extensão do pedido de alimentos gravídicos aos parentes em condições de pagá-los, porquanto, como já dito, o objetivo primordial é resguardar a saúde da gestante.

\subsection{AÇÃO DE ALIMENTOS GRAVÍDICOS}

Mesmo que não extensa, a Lei de Alimentos Gravídicos estabeleceu regras procedimentais distintas, as quais merecem ser examinadas.

E quando se fala em ação de alimentos gravídicos, o primeiro ponto a ser tratado é a petição inicial. Além dos mencionados indícios de paternidade, a exordial deve ser instruída com prova efetiva da gravidez. Muito embora a lei não fale expressamente em como deve ser feita essa prova, por óbvio que se trata de pressuposto para aquisição do direito a esses alimentos.

${ }^{16}$ Carlos Roberto Gonçalves, Direito civil brasileiro, p. 546.

17 "A doutrina e a jurisprudência são tranquilas no sentido da admissibilidade do pedido de complementação, não possuindo o pai legitimação ou interesse para insurgir-se contra tal litisconsórcio passivo, que no caso é facultativo impróprio, pois não lhe causa prejuízo algum formal ou material." (Carlos Roberto Gonçalves, Direito civil brasileiro, p. 545).

${ }^{18}$ Rosa Maria de Andrade Nery, Manual de direito civil: família, p. 378. 
Logo, é possível entender que, desde que apta a comprovar o estado de gravidez da parte autora, a prova deve ser admitida em juízo.

Uma vez admitida a petição inicial, o juiz designará audiência de conciliação. Comparecendo ambas as partes ao ato processual, poderá ser realizado e homologado acordo. Admite-se a autocomposição, pois, embora se trate de direito indisponível, a convenção tão somente versará sobre a forma como será exercitado esse direito, isto é, a quantia a ser paga, a forma, dia de pagamento etc.

Nos termos do artigo 190, do Código de Processo Civil, poderiam as partes ainda realizar os chamados "negócios jurídicos processuais atípicos", que consistem em pactos sobre mudanças procedimentais do processo, e têm como fundamento o dever de colaboração e a solução consensual de conflitos.

Sobre tal matéria, inclusive, tratou a $16^{\mathrm{a}}$ Câmara Cível do Tribunal de Justiça do Estado do Rio Grande do Sul, ao reconhecer "plenamente válido - e em consonância com o espírito do novo diploma processual - o ajuste firmado pelas partes para nova tentativa de conciliação, correndo o prazo defensivo somente a partir dessa segunda audiência" (Apelação Cível $\mathrm{n}^{\circ}$ 0313361-11.2017.9.21.7000, Rel. Des. Paulo Sérgio Scarparo, j. 26.10.2017, v.u.).

Assim, presentes os pressupostos dos negócios processuais (manifestação de vontade, autorregramento de vontade e referibilidade a um procedimento $)^{19}$, desde que não haja prejuízo à efetividade do direito da gestante, caberia também, nesse momento, a realização de tal negócio jurídico, mediante controle de validade pelo juiz.

Porém, se mesmo citado e intimado, o réu não comparecer à audiência ou, comparecendo, não realizar acordo, começa a fluir o prazo de cinco dias para apresentação de resposta (artigo $7^{\circ}$, da Lei n ${ }^{\circ} 11.804 / 08$ ).

A citação, por sua vez, não tem o condão de condicionar o termo inicial do pagamento de alimentos. O que se entende, nesse caso, é que o termo inicial pode se dar em três momentos: 1) na data da concepção; 2) na data do ajuizamento da ação; ou 3) na data do despacho inicial.

Contudo, no que tange aos alimentos gravídicos, houve veto de um dos artigos da lei, exatamente para não permitir que o alimentante se esquive da citação, visando, assim, a protelar sua responsabilidade. Por isso

\footnotetext{
${ }^{19}$ Teresa Arruda Alvim Wambier...[et al.], coordenadores. Breves Comentários ao Novo Código de Processo Civil. São Paulo: Editora Revista dos Tribunais, 2015, p. 591.
} 
mesmo, o artigo $2^{\circ}$, habilmente, demarcou o período de gravidez como sendo o de incidência dos alimentos gravídicos, os quais são devidos "da concepção ao parto".

É certo que, nas demais ações de alimentos, predomina o entendimento de que os alimentos fixados retroagem à data da citação, conforme disposição do artigo $13, \S 2^{\circ}$, da Lei de Alimentos. Igualmente, a súmula 277, do Superior Tribunal de Justiça.

Todavia, referindo-se aos alimentos gravídicos, deve se firmar que o termo inicial do pagamento é a concepção, de forma que, à época da citação, já haverá obrigação pré-existente. Afinal, "pai assim o é desde a concepção do filho". ${ }^{20}$

Quanto ao despacho inicial, prevalece a regra do artigo $4^{\circ}$, da Lei de Alimentos, segundo o qual o juiz fixa, desde logo, os alimentos provisórios. E é essencial que se aplique tal dispositivo aos alimentos gravídicos, haja vista a omissão da lei específica sobre o tema, o que poria em risco a efetivação desse direito.

Ora, não são poucas as vezes em que o nascimento da criança ocorre antes da prolação da sentença definitiva. Se fosse necessário aguardar a decisão final, poderia ocorrer o injusto outrora realçado: à gestante não seria deixada outra opção, senão a de suportar sozinha os custos da gravidez. Não bastasse, teria que fazê-lo na condição de grávida.

Assim, nada mais indicado que a admissão dos alimentos gravídicos provisórios, mesmo que com base em indícios de paternidade.

Ademais, no momento da fixação do valor, aduz o artigo $6^{\circ}$ que o juiz levará em consideração as necessidades da parte autora e as possibilidades da parte ré. Entende-se, no entanto, que referida norma deve ser interpretada com cautela. Afinal, já se havia determinado, no artigo $2^{\circ}$, que os alimentos gravídicos se limitam a cobrir as despesas adicionais do período de gravidez e que sejam dela decorrentes.

Portanto, é no limite dessas despesas que será analisado o binômio necessidade-possibilidade, quando da fixação dos alimentos. Assim, pode-se dizer que, de certa forma, houve uma relativização do princípio da proporcionalidade, exatamente pelo fato de que os alimentos gravídicos não guardam relação apenas com os ganhos do alimentante, mas também com as mencionadas despesas.

${ }^{20}$ Máxima sustentada pelo Instituto Brasileiro de Direito de Família. 
E ainda, discute-se a possibilidade ou não de presunção da necessidade da gestante. De um lado, há aqueles que defendam se tratar de necessidade presumida, não precisando a mulher produzir prova nesse sentido, e tão somente de sua gravidez. ${ }^{21}$ De outro, há quem sustente competir à gestante o ônus de provar a sua necessidade. ${ }^{22}$

No entanto, mais uma vez, não parece se tratar de controvérsia de difícil solução. A lei é precisa ao estatuir que se trata de um direito da mulher gestante, e que tanto ela quanto o futuro pai deverão arcar proporcionalmente com os gastos advindos da gestação. Nenhuma justificativa se encontra para simplesmente escusar o alimentante de seu dever. A presunção da necessidade da gestante é de rigor, questão sobre a qual os Tribunais não divergem. Veja-se:

\begin{abstract}
Alimentos gravídicos - Indícios de paternidade - Correta fixação Gestante - Necessidade presumida - Comprovação das possibilidades - Decisão mantida. "1)- Nos termos do artigo $6^{\circ}$ da Lei $\mathrm{n}^{\circ} 11.804 / 2008$, "convencido da existência de indícios da paternidade, o juiz fixará alimentos gravídicos que perdurarão até o nascimento da criança, sopesando as necessidades da parte autora e as possibilidades da parte ré." 2)- Possível a fixação dos alimentos gravídicos quando, em audiência de justificação, testemunha traz indício de prova da paternidade do nascituro. 3)- Os alimentos gravídicos compreendem valores suficientes para cobrir as despesas referentes ao período de gravidez e que sejam dela decorrentes, uma vez que a necessidade em caso de gestante é presumida. 4) - Demonstradas as possibilidades do agravante em arcar com os alimentos no importe fixado, não há motivo para reforma da decisão atacada. 5)- Recurso conhecido e não provido." (Agravo de Instrumento $\mathrm{n}^{\circ} 74389120128070000,5^{\mathrm{a}}$ Turma Cível do Tribunal de Justiça do Distrito Federal, Rel. Des. Luciano Moreira Vasconcellos, j. 06/06/2012). (grifou-se)
\end{abstract}

Por esse motivo que os alimentos já são ditos indisponíveis e irrenunciáveis: são imprescindíveis para quem os pleiteia, mas, mesmo assim, busca-se não onerar nenhuma das partes. De um lado, evita-se fixar um valor muito baixo em relação às necessidades do requerente e, de outro, arbitrar uma quantia muito alta em relação às possibilidades do requerido.

Com todo o respeito à construção divergente, condicionar um direito tão essencial à prova da necessidade, considerando ainda que a lei nada dispôs sobre isso, representaria uma total afronta ao princípio da

\footnotetext{
${ }^{21}$ Maria Berenice Dias, Manual de direito das famílias, p. 561

${ }^{22}$ Carlos Roberto Gonçalves, Direito civil brasileiro, p. 576
} 
paternidade responsável, consagrado constitucionalmente em nosso ordenamento jurídico (artigo 226, $\S 7^{\circ}$, da Constituição Federal).

Registre-se, ainda, que o juiz não está adstrito ao valor pleiteado ou ofertado em ação de alimentos ${ }^{23}$, podendo, inclusive, determinar sua redução em ação de exoneração. ${ }^{24}$ São diversos os julgados nesse sentido, os quais se pautam na compreensão de que se trata de exceção ao princípio da adstrição, de forma a não se configurar sentença extra petita ou ultra petita. Pode ainda, se entendê-lo prejudicial, não homologar eventual acordo.

No que diz respeito à sentença proferida em ação de alimentos, de se observar a regra contida no artigo 15, da Lei de Alimentos: "A decisão judicial sobre alimentos não transita em julgado e pode a qualquer tempo ser revista, em face da modificação da situação financeira dos interessados".

No entanto, já se consolidou entendimento doutrinário e jurisprudencial em sentido contrário, entendendo-se pela possibilidade da sentença de caráter alimentício transitar em julgado ${ }^{25}$, por não se vislumbrar qualquer motivo especial para que essa espécie de decisão não fizesse coisa julgada.

Ora, o próprio artigo 15 dispõe sobre a ação revisional de alimentos, no caso de sobrevir mudança da situação financeira de uma das

\footnotetext{
${ }^{23}$ Apelação cível. Ação de alimentos cumulada com guarda. Verba alimentar arbitrada. Insurgência recursal. Julgamento extra petita. Fixação em patamar diverso do pleiteado na inicial. Valores meramente estimativos. Arbitramento que observa o binômio necessidade e possibilidade. Sentença mantida. Recurso desprovido. "O Superior Tribunal de Justiça já firmou o entendimento de que, 'na ação de alimentos, a sentença não se subordina ao princípio da adstrição, podendo o magistrado arbitrá-los com base nos elementos fáticos que integram o binômio necessidade/capacidade, sem que a decisão incorra em violação dos arts. 128 e 460 do CPC' (STJ, AgRg no AREsp n. 603.597/RJ, rel. Min. Raul Araújo, Quarta Turma, j. Em 16-6-2015, dje 3-8-2015). " (Apelação Cível no 20160056374 Itapema 2016.005637-4, $3^{\text {a }}$ Câmara de Direito Civil do Tribunal de Justiça de Santa Catarina, rel. Des. Fernando Carioni, j. 15/03/2016). (grifou-se)

${ }^{24}$ Agravo regimental no recurso especial. Direito de família. Exoneração de alimentos. Ausência de violação ao art. 535, I e II, do CPC. Redução do valor da pensão. Julgamento extra petita. Não ocorrência. Agravo não provido. "1. Não se constata violação ao art. 535, I e II, do Código de Processo Civil quando a col. Corte de origem dirime, fundamentadamente, todas as questões que lhe foram submetidas. Havendo manifestação expressa acerca dos temas necessários à integral solução da lide, ainda que em sentido contrário à pretensão da parte, fica afastada qualquer omissão, contradição ou obscuridade. 2. Nos termos da orientação jurisprudencial desta Corte Superior, "não é extra petita a sentença que, diante do pedido de exoneração total de pensão, defere a redução dos alimentos. Como se sabe, no pedido mais abrangente se inclui o de menor abrangência" (REsp 249.513/SP, Rel. Ministro Sálvio de Figueiredo Teixeira, Quarta Turma, julgado em 6/3/2003, p. 289). 3. Agravo regimental a que se nega provimento." (Agravo Regimental no Recurso Especial n ${ }^{\circ}$ 1352321/PB, $4^{\mathrm{a}}$ Turma do Superior Tribunal de Justiça, Rel. Ministro Raul Araújo, j. 24/02/2015). (grifou-se)

${ }^{25}$ Maria Berenice Dias, "Princípio da proporcionalidade para além da coisa julgada".
} 
partes, seja para majorar ou para minorar o valor dos alimentos. E considerando que a ação revisional possui pedido e causa de pedir próprios, distintos dos inerentes à ação de alimentos, é de se concluir que a sentença faz coisa julgada, mas ulteriores mudanças em nada ofendem a imutabilidade do decidido. Inclusive, trata-se de relação jurídica continuativa, motivo pelo qual faz incidir a cláusula rebus sic stantibus, e de nenhuma forma se desconsidera a decisão judicial anterior.

Porém, aqui não se pretende levantar maiores questionamentos sobre os aspectos da ação revisional, e sim sobre a sua viabilidade ou não no âmbito dos alimentos gravídicos.

Em um país como o Brasil, cujo Poder Judiciário se encontra sobrecarregado, sendo assim conhecida a morosidade na tramitação dos processos, difícil se imaginar que uma sentença de alimentos gravídicos seja proferida antes do nascimento da criança, tendo em vista, principalmente, o breve intervalo de tempo entre este evento e a descoberta efetiva da gravidez.

Trata-se de um lapso de meses. Porém, mesmo assim, há que se indagar se, no caso de ser prolatada sentença antes do nascimento da criança, poderia ser ajuizada ação revisional. E, tendo em vista que seu cabimento seria benéfico para ambas as partes, não se visualiza qualquer impedimento. Satisfeitos os requisitos da revisional, entende-se pela possibilidade de seu ajuizamento, tanto por parte da gestante, como pelo futuro pai, e ainda mesmo que essa modificação venha a incidir em período próximo do parto.

Mas há que se defender essa possibilidade, acima de tudo, pelo fato de que, com o nascimento, os alimentos gravídicos são convertidos em alimentos para a criança. Tendo em vista que o valor continuará a ser pago no quantum fixado, justo que ele satisfaça o binômio necessidadepossibilidade, o que vem a beneficiar os dois lados.

Por fim, ocorrendo interrupção da gravidez durante o processo, não será exigida restituição dos valores já pagos, e ocorrerá consequente extinção do feito. Nesse caso, possível o entendimento de que o direito a alimentos gravídicos se extingue de forma automática (diferentemente das demais espécies de alimentos, que exigem decisão judicial declarando sua extinção, conforme súmula 358, do Superior Tribunal de Justiça).

\subsection{INDÍCIOS DE PATERNIDADE E EXAME DE DNA}


Embora já fossem concedidos alimentos gravídicos antes da edição de lei especial, a Lei $n^{\circ} 5.478$, de 1968, que era a que prevalecia para a aplicação do direito a qualquer espécie de alimentos, indubitavelmente, representava um obstáculo para essa concessão. Isso porque exigia, em seu artigo $2^{\circ}$, prova do parentesco ou da obrigação alimentar do devedor, a qual era pré-constituída no momento do ajuizamento da ação, ou então era produzida em sede de ação investigatória de paternidade.

Como, então, poderiam as gestantes produzir essa prova, sem que efetivamente houvesse uma criança para se submeter ao exame pertinente à investigação de paternidade? Foi a partir desse questionamento que o legislador, com boa dose de razoabilidade, editou a seguinte regra (artigo $6^{\circ}$, da Lei $n^{\circ} 11.804$, de 2008):

"Convencido da existência de indícios da paternidade, o juiz fixará alimentos que perdurarão até o nascimento da criança, sopesando necessidades da parte autora e as possibilidades da parte ré."

Trata-se de uma das maiores novidades trazidas pela lei e, ao mesmo tempo, um dos maiores alvos de crítica quando se fala em alimentos gravídicos. Contudo, nada a legislação dispunha sobre a situação específica das gestantes, que ficavam desamparadas para a tutela de suas necessidades gravídicas, diante da dificuldade de produzir tal prova (comprovação da obrigação alimentar ou do vínculo do parentesco).

No entanto, com a edição da Lei de Alimentos Gravídicos e, precisamente, com seu artigo $6^{\circ}$, dispensou-se de vez a prova da paternidade, porquanto de inviável produção, sequer sendo exigida a cumulação com ação de investigação de paternidade (esta já não era exigida).

A explicação é das mais exemplares: uma vez que é de consenso na comunidade médica que o exame de DNA (ácido desoxirribonucleico) realizado em gestantes pode comprometer a gestação ${ }^{26}$, seria paradoxal se ele fosse exigido para instruir o pedido de alimentos.

Desse modo, visando a equilibrar uma situação de desigualdade, a qual unicamente se prestava a legitimaras esquivas de alguns pais de enfrentar suas responsabilidades, entendeu o legislador pela

\footnotetext{
${ }^{26}$ Douglas Phillips Freitas, “Alimentos Gravídicos e a Lei n. 11.804/2008 - Primeiros reflexos”.
} 
admissibilidade de outros meios para, se não provar, ao menos indicar uma provável paternidade.

São os chamados indícios de paternidade, consistentes em elementos aptos a demonstrar que, muito provavelmente, aquele chamado para responder à ação será o pai. Ou melhor: já é o pai. Afinal, o que se sustenta é que a responsabilidade paterna tem início com a concepção, motivo pelo qual esse é o termo inicial da obrigação alimentar. Por isso, a máxima sustentada pelo Instituto Brasileiro de Direito de Família, já aqui mencionada anteriormente: "pai assim o é desde a concepção do filho".

A lei, novamente, acabou por não explicar ou sequer exemplificar quais seriam esses indícios. Compreensível, no entanto, a decisão do legislador, porquanto é vasta a possibilidade de elementos que venham a indicar paternidade e que possam instruir a exordial, ainda mais diante da frenética evolução da tecnologia, que cada vez mais adentra nos espaços particulares dos indivíduos e das relações interpessoais, deixando pouca ou quase nenhuma margem para a privacidade.

No entanto, é de extrema relevância assinalar que, mesmo que os indícios de paternidade representem um fundamento probatório frágil, não devem ser confundidos com a mera imputação de paternidade. Exatamente pelo fato de os alimentos gravídicos se originarem, em geral, de relacionamentos não estabilizados, não há possibilidade de se configurar qualquer hipótese de filiação presumida, nos termos dos artigos 1.597 a 1.602, do Código Civil.

É nesses indícios que reside a maior resistência para se conceder alimentos gravídicos, vez que, em tese, indivíduos que não são os verdadeiros pais poderiam ser condenados ao seu pagamento, e sequer teriam direito de restituição (quando sobreviesse prova negativa da paternidade), em razão da irrepetibilidade dos alimentos - a qual apenas não se aplicaria nos casos em que a gestante agisse de má-fé, ingressando com a ação contra aquele que sabidamente não é o pai.

Os julgadores têm então se mostrado cautelosos quando da apreciação dos indícios trazidos pela gestante para formar sua convicção. Decerto que não podem exigir realização do exame de DNA - inclusive em caso de negativa de paternidade -, seja porque perigoso para o nascituro, seja porque invasivo para a gestante. Todavia, é evidente que tentam coibir eventual má-fé por parte da autora, de forma que em nenhum momento é negada a ampla defesa do indigitado pai. 
Logo, não gozando o mero pedido alimentar de presunção de veracidade, não se podendo exigir prova negativa a ser realizada pelo réu e cabendo à autora o ônus probatório, conclui-se que a petição inicial deve ser instruída, não com prova robusta, mas com dados verossimilhantes da alegada paternidade.

Percebe-se, pois, que o discernimento do juiz é fundamental. Quer dizer, sempre o é, em razão de não mais prevalecerem os sistemas de prova tarifada e o da íntima convicção. Entretanto, notadamente no caso dos alimentos gravídicos, denota-se maior expressividade na convicção do julgador, que não se baseia em provas concretas, e sim em indícios, que sequer foram conceituados ou exemplificados na legislação.

Assim, julgados de tribunais de todo o país têm sido de grande utilidade para a formação de precedentes, e por isso serão indicados a seguir.

Agravo de instrumento. Ação de alimentos gravídicos. Possibilidade, no caso. "1. Em sede de cognição sumária, o requisito exigido à concessão de alimentos gravídicos ("indícios de paternidade", nos termos do art. $6^{\circ}$ da Lei $\mathrm{n}^{\circ} 11.804 / 08$ ) deve ser examinado sem muito rigorismo, tendo em vista a dificuldade na comprovação do alegado vínculo de parentesco já no momento do ajuizamento da ação, sob pena de não se atender à finalidade da lei, que é a de proporcionar ao nascituro seu sadio desenvolvimento. 2. No caso, comprovando o exame médico a gestação e havendo declarações de três pessoas acerca da relação amorosa mantida entre a autora e o suposto pai, em período concomitante à concepção, há plausibilidade na indicação de paternidade realizada pela agravante, restando autorizado o deferimento dos alimentos gravídicos, no valor de $30 \%$ do salário mínimo. Agravo de instrumento parcialmente provido." (Agravo de Instrumento $\mathrm{n}^{\circ}$ 70061965919, 8 a Câmara Cível do Tribunal de Justiça do Rio Grande do Sul, Rel. Des. Ricardo Moreira Lins Pastl, j. 20/11/2014). (grifou-se)

Agravo de instrumento. Ação de alimentos gravídicos. Possibilidade, no caso. "1. O requisito exigido para a concessão dos alimentos gravídicos, qual seja, "indícios de paternidade", nos termos do art. $6^{\circ}$ da Lei $n^{\circ} 11.804 / 08$, deve ser examinado, em sede de cognição sumária, sem muito rigorismo, tendo em vista a dificuldade na comprovação do alegado vínculo de parentesco já no momento do ajuizamento da ação, sob pena de não se atender à finalidade da lei, que é proporcionar ao nascituro seu sadio desenvolvimento. 2. No caso, considerando os documentos que comprovam a gestação, as fotografias e, especialmente, as conversas mantidas entre a autora e o suposto pai em site de relacionamento, que evidenciam a existência de relação amorosa no período concomitante à concepção, há plausibilidade na indicação de paternidade realizada pela agravante, restando 
autorizado o deferimento dos alimentos gravídicos, no montante de $30 \%$ do salário mínimo. Agravo de instrumento parcialmente provido, por maioria." (Agravo de Instrumento ${ }^{\circ} 70058670852,8^{a}$ Câmara Cível do Tribunal de Justiça do Rio Grande do Sul, Rel. Des. Ricardo Moreira Lins Pastl, j. 10/04/2014). (grifou-se)

Processo civil. Agravo de instrumento. Decisão que não fixa alimentos gravídicos provisórios. Devida. Indícios de paternidade. Não verificados. Decisão mantida. "1- Inobstante concordar com a agravante que não é apenas em situações em que restem demonstradas a existência de união estável ou o casamento entre as partes que poderão ser concedidos os alimentos gravídicos, entendo que os indícios devem ser sérios, ou seja, devem ser suficientes, pelo menos em princípio, a formarem uma certeza no magistrado de que há elementos, mesmo que mínimos, de que o réu possa ser, em efetivo, pai do nascituro. 2- Meras fotos com o agravado, conforme se verifica às fls. 28/32 não são provas indiciárias sérias da paternidade. 3- Negado provimento ao agravo." (Acórdão n 991609, 20160020450500AGI, $3^{\text {a }}$ Turma Cível do Tribunal de Justiça do Distrito Federal, Rel. Des. Gilberto Pereira de Oliveira, j.01/02/2017). (grifou-se)

Agravo de instrumento - Ação de alimentos gravídicos Concessão dos alimentos na primeira instância - Nascimento da criança - Manutenção do processamento do feito - Inexistência de indícios suficientes da existência de relacionamento concomitante à concepção - Prova documental insuficiente - Decisão reformada - Agravo provido. "O nascimento da criança em favor da qual se postulou alimentos gravídicos não acarreta a extinção do processo, uma vez que, nesses casos, a Lei ${ }^{\circ} 11.804 / 2008$ prevê a conversão do instituto em pensão alimentícia. Os alimentos gravídicos previstos na Lei $\mathrm{n}^{\mathrm{o}} 11.804 / 2008$ se destinam a assegurar a subsistência da mulher gestante, bem assim a custear as despesas decorrentes da gravidez, com vistas à manutenção digna do nascituro, dispensando-se, para a sua concessão, a prova robusta da paternidade, exigindo-se apenas elementos que indiquem relacionamento amoroso contemporâneo à concepção. Caso em que constam dos autos unicamente fotografias em que as partes aparecem juntas, as quais não indicam de forma suficiente a existência do relacionamento ou o período em que tal união teria ocorrido, sendo impositiva a revogação da obrigação imposta ao Agravante, sem prejuízo de que, à luz de novos fatos e provas, a obrigação seja restabelecida na primeira instância. Decisão reformada. Agravo provido." (Agravo de Instrumento $n^{\circ} 0015720$ 70.2015.8.05.0000, $3^{\text {a }}$ Câmara Cível do Tribunal de Justiça da Bahia, Rel. Des. Telma Laura Silva Britto, publicado em 25/05/2016). (grifou-se)

Agravo de instrumento. Ação de alimentos. Gravídicos fixados no equivalente a $10 \%$ dos vencimentos líquidos do agravante. Alegação de que a autora deixou de comparecer à audiência destinada à abertura do exame de DNA não comprovada. Também não demonstrada incapacidade de arcar com o percentual 
razoavelmente arbitrado. Demanda ainda sujeita a dilação probatória na origem. Manutenção da decisão provisória assentada na proteção da gestação. Agravo improvido. "O Agravante se rebelou contra a decisão de piso que fixou alimentos gravídicos no importe de 10 dos seus vencimentos líquidos. A prova da paternidade não é exigida na espécie e o juiz deve aferir a presença de indícios suficientes para formar o seu convencimento. Nos autos, o Agravante não negou a existência de Boletim de Ocorrência com pedido de medida protetiva relacionada a ameaças de agressão contra a Autora e nem mesmo trouxe aos autos o parecer favorável emitido pelo MP de primeiro grau, subtraindo a condição recursal de averiguar com mais substância o conteúdo probante, ante a limitada cognição própria do Agravo de instrumento. Nesse contexto, não negado o relacionamento $e$ presente a gestação, há de persistir a decisão que provisoriamente fixou os alimentos em percentual razoável. Frise-se, por fim, que o Agravante alega mais não prova outras três prestações alimentares e nem o comprometimento de sua capacidade financeira. Decisão de piso em sintonia com pareceres Ministeriais de ambos os graus. Juridicidade presente. Agravo Improvido." (Agravo de Instrumento $\mathrm{n}^{\circ}$ 0012804-63.2015.8.05.0000, $3^{\mathrm{a}}$ Câmara Cível do Tribunal de Justiça da Bahia, Rel. Des. Maria do Socorro Barreto Santiago, publicado em 23/09/2015). (grifou-se)

Agravo de instrumento. Ação de investigação de paternidade. Alimentos provisórios. "Ausência de fortes e convincentes indícios da paternidade. Juntada de certidão de batismo, cujo conteúdo é controvertido. Arbitramento afastado. Agravo provido." (Agravo de Instrumento ${ }^{\circ} 5574544300,3^{a}$ Câmara de Direito Privado do Tribunal de Justiça de São Paulo, Rel. Des. Donegá Morandini, j. 26/08/2008). (grifou-se)

Alimentos gravídicos. Autora comprovou relacionamento com o réu no período da concepção. Prova oral é suficiente para a pretensão da pensão alimentícia provisória especial. Desnecessidade de comprovação da paternidade. Devido processo legal observado. Sucumbência levou em consideração as peculiaridades da demanda. Apelo desprovido. Alimentos gravídicos. "Autora comprovou relacionamento com o réu no período da concepção. Prova oral é suficiente para a pretensão da pensão alimentícia provisória especial Desnecessidade de comprovação da paternidade. Devido processo legal observado. Sucumbência levou em consideração as peculiaridades da demanda. Apelo desprovido." (Apelação Cível no 032429264.2009.8.26.0000, $4^{\mathrm{a}}$ Câmara de Direito Privado do Tribunal de Justiça de São Paulo, Rel. Des. Natan Zelinschi de Arruda,j. 26/11/2009). (grifou-se)

Logo, o entendimento dos tribunais se coaduna com o que vem sendo sustentado: considerando que o processo de alimentos gravídicos se dá em sede de cognição sumária, podem ser aceitas, como indícios de 
paternidade, todas as informações capazes de apontar uma provável paternidade.

Na hodiernidade, considerando o aplicativo Whatsapp e a rede social Facebook como dois dos maiores veículos de comunicação existentes, é comum que sejam apresentadas, em juízo, cópias de conversas entre as partes nesses dois sítios eletrônicos. Seja um rápido encontro, um namoro, ou uma relação sexual (especialmente durante o período fértil da mulher), as palavras trocadas entre o casal têm se mostrado cruciais para a produção probatória em análise.

O surgimento de aplicativos de relacionamento propicia ainda mais a possibilidade de se estabelecer contato com diversos parceiros em potencial, por meio da seleção de perfis compatíveis entre si, conversas simultâneas e encontros efêmeros. O resultado é o massivo armazenamento de dados pessoais de todos os seus usuários, dados esses que não demorarão para figurar no Judiciário como provas indiciárias de paternidade.

Em certo caso, como foi possível observar, contentou-se o julgador com a prova testemunhal que dava conta do relacionamento entre as partes. Em outro, foi levada em consideração a ausência de negativa de paternidade pelo réu.

No entanto, a depender das conversas e fotos juntadas, ou dos testemunhos prestados, os indícios podem ser considerados insuficientes. A negativa de paternidade ofertada pelo réu, por exemplo, não é suficiente para afastar os indícios, mas, somada a outros elementos de convicção, pode conduzir ao indeferimento do pedido inicial.

Por isso que, de fato, acertou o legislador em não querer oferecer parâmetro para a essa apreciação, sendo confiada ao prudente arbítrio do julgador a análise das provas. Aquilo que foi considerado indício em um processo pode não ser considerado em outro, motivo pelo qual, em cada caso, deve o juiz se atentar a todas as circunstâncias que envolvem a situação.

A título de exemplo, tem-se o um julgado do Tribunal de Justiça do Rio Grande do Sul em que uma simples nota fiscal em nome do suposto pai e referente à compra de um berço infantil foi apreciada como indício de paternidade, e conduziu à fixação de alimentos gravídicos provisórios:

Agravo de instrumento. Ação de alimentos gravídicos. Possibilidade, no caso. " 1 . O requisito exigido para a concessão dos alimentos gravídicos, qual seja, "indícios de paternidade", nos 
termos do art. $6^{\circ}$ da Lei $n^{\circ} 11.804 / 08$, deve ser examinado, em sede de cognição sumária, sem muito rigorismo, tendo em vista a dificuldade na comprovação do alegado vínculo de parentesco já no momento do ajuizamento da ação, sob pena de não se atender à finalidade da lei, que é proporcionar ao nascituro seu sadio desenvolvimento. 2. No caso, a nota fiscal relativa à aquisição de um berço infantil em nome do agravado, juntada ao instrumento, confere certa verossimilhança à indicação da insurgente acerca do suposto pai, o que autoriza, em sede liminar, o deferimento dos alimentos gravídicos postulados, no valor de $30 \%$ do salário mínimo, quantia significativamente módica." (Agravo de Instrumento $\mathrm{n}^{\mathrm{o}} 70046905147,8^{\mathrm{a}}$ Câmara Cível do Tribunal de Justiça do Rio Grande do Sul, Rel. Des. Ricardo Moreira Lins Pastl, j.22/03/2012). (grifou-se)

É lícito, portanto, concluir que, reconhecidos os indícios, a decisão concessiva de alimentos gravídicos equivaleria ao reconhecimento de paternidade em caráter cautelar, cuja confirmação só ocorreria com o nascimento. ${ }^{27}$

De qualquer forma, não se pode desmerecer o instituto dos alimentos gravídicos tão somente pelo fato de se pautarem em indícios, e não em provas cabais.

Casos midiáticos, como o da "falsa grávida de Ribeirão Preto"28, são erroneamente utilizados como crítica à falta de rigorismo dos alimentos gravídicos, e fazem parecer que é de costume indivíduos que não são os pais serem condenados ao pagamento de alimentos. Entretanto, como foi explanado, os indícios de paternidade em nada violam as garantias constitucionais do devido processo legal. Realmente, são analisados em sede de cognição sumária, da mesma forma que ocorre com pedidos cautelares, em que há urgência na obtenção da tutela.

Consequentemente, verifica-se que se trata de instituto que ainda muito será objeto de discussões, em razão do irrefreável avanço da tecnologia e da medicina, permitindo-se, cada vez mais, a ampliação dos meios de obtenção de prova.

Por ora, enquanto não surge meio seguro de comprovar cabalmente a paternidade durante a gravidez sem apresentar riscos,

\footnotetext{
${ }^{27}$ Rosa Maria de Andrade Nery, Manual de direito civil: família, p. 378.

${ }^{28}$ Trata-se de caso em que, mediante uso de documentos falsos e outros meios artificiosos, uma mulher obteve a concessão de alimentos gravídicos, por meio de ação de própria, sendo que sequer se encontrava grávida. Os alimentos restaram pagos durante o período da gravidez e cerca de um ano após o suposto nascimento. Tais fatos ainda são objeto de investigação no âmbito criminal, mas encontramse discriminados no seguinte site: https://g1.globo.com/sp/ribeirao-preto-franca/noticia/jovem-esuspeita-de-inventar-gravidez-para-se-vingar-do-ex-e-fazer-ate-falsa-festa-de-1-ano-do-bebe.ghtml.
} 
continua vigorando a expressão latina pater is est, quem nuptiae demonstrant $t^{29}$, a qual demonstra que, desde sempre, admite-se a presunção da paternidade em razão de indícios de verossimilhança.

\subsection{CONVERSÃO AUTOMÁTICA APÓS O NASCIMENTO}

Os alimentos gravídicos perduram até o nascimento da criança, momento em que são convertidos em alimentos em seu favor. É o que preconiza o parágrafo único, do artigo $6^{\circ}$, da Lei no 11.804 , de 2008.

Ao editar essa norma, a intenção do legislador foi exatamente a de não obrigar a mãe - agora na condição de representante legal de seu filho - a ingressar mais uma vez em juízo para fazer valer o direito alimentício. Se já necessitava de alimentos antes, porque não mais se encontrava na companhia de seu parceiro, não há porque fazer supor que, com o nascimento, deixaria de os necessitar. Até porque a necessidade da criança é presumida, assim como também o era a da gestante.

Exigir o ajuizamento de nova ação de alimentos representaria excessivo formalismo do legislador e geraria o deslocamento do termo inicial da obrigação, o que apenas se prestaria a confortar o comportamento do devedor que não quisesse cumprir com seu dever alimentar, protelandoo ao máximo.

Dessa forma, à luz dos princípios da instrumentalidade das formas e da economia processual, bem como do fundamento da República Federativa do Brasil da dignidade da pessoa humana, foi determinada a conversão automática dos alimentos gravídicos em alimentos para a criança, o que se opera com seu nascimento.

Em recente julgado ${ }^{30}$, o Superior Tribunal de Justiça debateu sobre a questão da conversão automática e, com votação unânime, decidiu por sua legalidade.

$\mathrm{O}$ argumento utilizado pelo recorrente, nesse processo, foi o de que o nascimento do filho implicaria mudança da legitimidade ativa e extinção da obrigação alimentar existente durante a gestação, de forma que os alimentos gravídicos não mais poderiam ser executados. Ademais,

\footnotetext{
29 "O pai é aquele que o matrimônio designa como tal".

${ }^{30}$ Recurso Especial n ${ }^{\mathrm{o}}$ 1.629.423 SP, $3^{\mathrm{a}}$ Turma, Rel. Ministro Marco Aurélio Bellizze, j. 06/05/17, v.u.
} 
arguiu-se que deveria ter sido realizado pedido expresso de mantença dos alimentos após o nascimento e, não o sendo, teria se verificado a preclusão.

Ocorre que tanto o Ministério Público quanto os julgadores entenderam que não assistia razão ao recorrente, posto que, com o nascimento da criança, a ação não perderia seu objeto. Em síntese, o entendimento do tribunal:

Recurso especial. Constitucional. Civil. Processual civil. Alimentos gravídicos. Garantia à gestante. Proteção do nascituro. Nascimento com vida. Extinção do feito. Não ocorrência. Conversão automática dos alimentos gravídicos em pensão alimentícia em favor do recém-nascido. Mudança de titularidade. Execução promovida pelo menor, representado por sua genitora, dos alimentos inadimplidos após o seu nascimento. Possibilidade. Recurso improvido. "1. Os alimentos gravídicos, previstos na Lei n. 11.804/2008, visam a auxiliar a mulher gestante nas despesas decorrentes da gravidez, da concepção ao parto, sendo, pois, a gestante a beneficiária direta dos alimentos gravídicos, ficando, por via de consequência, resguardados os direitos do próprio nascituro. 2. Com o nascimento com vida da criança, os alimentos gravídicos concedidos à gestante serão convertidos automaticamente em pensão alimentícia em favor do recém-nascido, com mudança, assim, da titularidade dos alimentos, sem que, para tanto, seja necessário pronunciamento judicial ou pedido expresso da parte, nos termos do parágrafo único do art. $6^{\circ}$ da Lei n. 11.804/2008. 3. Em regra, a ação de alimentos gravídicos não se extingue ou perde seu objeto com o nascimento da criança, pois os referidos alimentos ficam convertidos em pensão alimentícia até eventual ação revisional em que se solicite a exoneração, redução ou majoração do valor dos alimentos ou até mesmo eventual resultado em ação de investigação ou negatória de paternidade. 4. Recurso especial improvido." (Recurso Especial no $1629423 / \mathrm{SP}, 3^{\mathrm{a}}$ Turma, Rel. Ministro Marco Aurélio Bellizze, j. 06/06/2017). (grifou-se)

Embora sejam muitas as críticas, no mesmo sentido daquelas formuladas pelo recorrente no processo supramencionado (mudança de legitimidade, preclusão do direito à conversão por falta de pedido etc.), elas não se coadunam com o propósito da lei, ou seja, o de afastar impedimentos insubsistentes para a efetivação do direito alimentar.

O que se infere contra essa conversão, em geral, é que o nascimento significaria mudança do fato constitutivo da pretensão e, consequentemente, do pedido. Sem nova ação ou citação, haveria inobservância do princípio do contraditório, tratando-se de pedido com base em fatos incertos. ${ }^{31}$

${ }^{31}$ Yussef Said Cahali, Dos Alimentos, p. 725. 
Em suma, interpreta-se a conversão automática como uma mudança da natureza dos alimentos, pois, em um primeiro momento (gestação), abrangiam determinadas necessidades (despesas da gravidez) e, em um segundo momento (nascimento), passariam a abranger outras (gastos da criança). A novidade, no entanto, é que não é necessário novo pedido de alimentos.

Logo, não é a conversão em si o alvo de críticas, mas o fato de que os alimentos antes e depois do nascimento possuem parâmetros de fixação diversos. Porém, foi exatamente pensando nesse impasse que se afigurou ser possível a fixação de valores diversos para atender às particularidades de cada situação. ${ }^{32}$

Ora, se tanto a necessidade da gestante quanto a da criança são presumidas, nada impede que o juiz, desde logo, fixe um valor a ser pago durante a gravidez, e outro após o nascimento. Afinal, já se sabendo que haverá conversão automática, a ideia é exatamente a de resguardar, de antemão, um direito. Eventual insuficiência ou exorbitância no valor poderão ser discutidas em ação revisional, ou até mesmo contestadas durante o trâmite da ação de alimentos gravídicos.

Porém, não obstante as críticas nesse assunto sejam dotadas de plausibilidade, deve-se levar em consideração que foi essa a melhor solução encontrada pelo legislador, pois foi a que se apresentou como mais garantista do direito a alimentos, o qual deve ser, a todo o momento, resguardado e prevenido de eventuais manobras protelatórias.

\subsection{ARTIGOS VETADOS}

O Projeto de Lei $n^{\circ} 7.376$, de 2006 ( $n^{\circ}$ 62/04 no Senado Federal), que deu origem à Lei de Alimentos Gravídicos, teve seis artigos vetados, em razão de "contrariedade ao interesse público e inconstitucionalidade".

De fato, os motivos que justificaram esses vetos já foram aqui praticamente exauridos. No entanto, é imprescindível que ao menos se discorra brevemente sobre cada um deles. Afinal, a ideia inicial do legislador era de que tais artigos $\left(3^{\circ}, 4^{\circ}, 5^{\circ}, 8^{\circ}, 9^{\circ}\right.$ e 10$)$ integrassem a lei, o que indica que, a todo o momento, são colocados desnecessários óbices perante a efetivação do direito da gestante.

\footnotetext{
${ }^{32}$ Maria Berenice Dias, Manual de direito das famílias, p. 561.
} 
Primeiramente, o artigo $3^{\circ}$ dispunha que o foro competente para processo e julgamento da ação de alimentos gravídicos seria o mesmo do artigo 94, do Código de Processo Civil de 1973. Em outras palavras, caberia à gestante se locomover até o domicílio do réu se quisesse ajuizar essa ação.

Assim, identificou-se, de pronto, total desprezo à condição especial da gestante. A esta, a bem da verdade, deveria ser dispensada maior consideração quando da fixação do foro competente. Exatamente por se encontrar grávida, não deveria ser exigido da mulher que se locomovesse até o local em que residisse o suposto pai. Se a ideia da lei era tutelar interesses da gestante, o artigo $3^{\circ}$ indubitavelmente atentava contra essa tutela, motivo pelo qual foi vetado.

Em segundo lugar, o artigo $4^{\circ}$ exigia que a petição inicial fosse instruída não apenas com laudo médico confirmando a gravidez, como também com atestado de sua viabilidade. Porém, sob argumento de que, viável ou não, a gravidez gera dispêndio financeiro, sendo obrigação daquele que viria a ser pai dividir despesas, tal dispositivo restou vetado, de forma que a viabilidade da gravidez não constitui pré-requisito para o pedido de alimentos gravídicos.

$\mathrm{O}$ artigo $5^{\circ}$, por sua vez, tornava obrigatória a designação de audiência de justificação, momento processual em que seriam apreciadas provas da paternidade em cognição sumária. Ocorre que, além de não se tratar de procedimento obrigatório para nenhuma outra ação de alimentos, essa obrigatoriedade certamente traria maior delonga ao processo, o que, notadamente, por se tratar de ação breve que perdura até o nascimento da criança, representaria absoluta contrariedade à intenção do legislador de ver o direito a alimentos gravídicos garantido ainda na gestação. Por isso, o veto.

Outro artigo que representava contraste ao espírito da lei era o $8^{\circ}$, cujo texto determinava que, em caso de oposição à paternidade por parte do réu, a procedência do pedido da autora ficaria condicionada à realização de "exame pericial pertinente". A razão do veto foi a de que, segundo a sistemática processual vigente, a perícia é elemento de prova, somente necessário diante da ausência de outros elementos probatórios, não constituindo condição à procedência da demanda.

Mais: não bastasse tamanho abuso sob a ótica processual, seria de igual desrespeito exigir da gestante a produção de uma prova que poderia colocar em risco sua gestação. Pior ainda condicioná-la à mera 
oposição do réu, o qual facilmente poderia fazê-lo se quisesse protelar sua obrigação.

Já o artigo $9^{\circ}$ tratava do termo inicial da obrigação alimentar, fixando-o na data da citação do réu. Porém, pela justificativa já apresentada anteriormente, qual seja, a de que o ato citatório poderia ser dolosamente retardado pelo réu, esse artigo também foi vetado.

Por fim, o artigo 10 previa a possibilidade de o réu pleitear danos morais e materiais, em caso de resultado negativo de exame pericial. Entendeu-se, no entanto, que se tratava de cerceamento do direito de acesso à justiça, previsto constitucionalmente, por criar, de forma intimidadora, responsabilidade objetiva pelo simples fato de se ingressar com a ação em juízo.

Não obstante, ainda persiste a possibilidade de responsabilização civil da autora com fundamento no artigo 186, do Código Civil. Sobre o assunto, a lição de Carlos Roberto Gonçalves:

"Afigura-se-nos, neste caso, razoável afirmar que não se pode ser
rigoroso na apreciação da conduta da mulher gestante, sob pena de
se criar uma excessiva restrição ao direito de postular em juízo, que
constituiria um perigoso risco para quem se dispusesse a exercê-lo.
Deve-se aplicar o mesmo critério recomendado para o caso de
oposição, de má-fé, de impedimentos ao casamento, comentado no
Título I, Capítulo V, item 1.3, retro, qual seja: somente a culpa que
revele uma total ausência de cautelas mínimas por parte da mulher
pode justificar a sua responsabilização, afastando-se as hipóteses
de culpa levíssima e até mesmo da culpa leve. Somente o dolo ou
culpa grave serviriam de fundamento para a sentença
condenatória."

\section{CONSIDERAÇÕES FINAIS}

Conclui-se que, praticamente, é pacífico o entendimento de que são devidos alimentos durante a gestação. Mesmo antes do advento da Lei $\mathrm{n}^{\circ}$ 11.804, de 2008, os alimentos gravídicos já faziam parte da realidade jurídico brasileira, mesmo que fossem pouco conhecidos. Porém, atualmente, são os seus pormenores que geram controvérsias, as quais, frequentemente, dificultam a aplicação efetiva da lei.

Não apenas em matéria civil e processual civil, as polêmicas ligadas aos alimentos gravídicos caminham ao lado de tabus, principalmente os que dizem respeito a discussões de sexo e de gênero, 
sendo de extrema urgência que essas questões sejam discutidas e, enfim, superadas.

Eles demonstram, em primeiro lugar, que as mães solteiras não restarão marginalizadas da sociedade, como se indignas fossem por manter relações sexuais com alguém que não é um parceiro estável e, assim sendo, indignas de receber auxílio do futuro pai. Demonstram, também, que a credibilidade da palavra da mulher em nada se confunde com a sua moral sexual, até porque são poucos os casos de improcedência de ações declaratórias de paternidade. ${ }^{33}$

Sem dúvidas de que, em projeção, a lei traz ganhos imensuráveis para o futuro filho. Todavia, para as mulheres, ela simboliza uma conquista histórica, social e legal, à medida que as liberta de um estigma e garante um direito fundamental.

Casos famosos na mídia são utilizados de forma equivocada na tentativa de demonstrar suposta fragilidade do direito aos alimentos gravídicos, sob o argumento de que poderiam ser facilmente cobrados e obtidos de um indivíduo que não é pai, em razão da desnecessidade de prova cabal da paternidade. O que se sustenta é que seria por demais negativa a repercussão na vida pessoal, social e financeira desse sujeito que foi injustamente condenado ao pagamento de alimentos.

Mais que uma falsa premissa, trata-se de uma refutação equivocada, advinda daqueles que pensam ser de fácil concessão o pedido de alimentos gravídicos, bem como daqueles que defendem ser mais importante resguardar o nome do genitor do que a sobrevivência da gestante e de seu filho.

Veja-se: não se nega que a condenação seria injusta e geraria referida repercussão na vida do condenado, mas o que se pretende mostrar é que, primeiramente, mesmo em sede de cognição sumária, o juiz se pauta em prova efetiva da gravidez e indícios significativos de paternidade. É com base nisso que haverá eventual concessão de alimentos, e não apenas o mero requerimento da autora. Em segundo lugar, caso condenado ao pagamento de alimentos gravídicos aquele que não é pai, basta proceder à investigação de paternidade, após o nascimento da criança, para real aferição do vínculo paterno. Inclusive, se comprovada a má-fé da genitora, ela poderá ser responsabilizada civilmente.

${ }^{33}$ Jones Figueirêdo Alves, “Alimentos do Ventre". 
Por outro lado, a gestante que não consegue obter alimentos gravídicos daquele que é, efetivamente, o pai da criança, não apenas terá comprometida sua vida social e pessoal. Afinal, nem sempre é com bons olhos que a sociedade enxerga a mãe solteira. Estará em risco a sua gestação e, consequentemente, o nascimento de seu filho. Nada poderá fazer para conseguir os alimentos caso não consiga levar aos autos os indícios de paternidade, ao mesmo tempo em que o pagamento tardio deles, após a realização do exame de DNA, dificulta ainda mais a efetividade desse direito.

Por mais honrada que seja a atitude do pai ao reembolsar a mãe, no que diz respeito às quantias por ela despendidas durante a gravidez, sem dúvidas que se trata de uma medida ineficaz, do ponto de vista daquilo que o instituto dos alimentos gravídicos realmente tutela, que é a dignidade da mulher na condição de gestante.

Ademais, há que se considerar que sobre o pai que se esquiva de sua obrigação alimentar raramente recai sanção mais grave que aquela decorrente da ação de execução de alimentos. Os costumes acabaram por naturalizar a imagem do genitor que abandona sua família, de forma que são usualmente enaltecidos aqueles que auxiliam seus entes, enquanto as mães não fazem mais que sua obrigação.

De fato, foram necessárias muitas mudanças sociais e quebras de paradigmas para que se pudesse alcançar o estágio de evolução legal que se tem hoje, mas, enfim, deve se reconhecer que o legislador houve por bem lembrar dessas mulheres que, até então, eram relegadas ao esquecimento.

Não se contesta que toda decisão proferida por um juiz está sujeita a equívocos, motivo pelo qual a análise de provas deve ser sempre feita com cautela. A má-fé deve ser coibida sempre, tanto por parte da gestante, como por parte do futuro pai, sob pena, nos dois casos, de se desmoralizar o instituto dos alimentos gravídicos. Pelo mesmo motivo, os demais operadores do direito, notadamente os advogados, não devem se utilizar da ação correspondente de forma temerária.

A luta pela efetivação do direito a alimentos gravídicos é constante e pertence a todos, visando à concretização de normas que já existem. Caso contrário, seria inútil o imenso repertório de leis e princípios consagrados na Lex Mater, se o Estado e a sociedade os olvidassem no dia a dia. 
A matéria foi bem destacada por Maria Berenice Dias, em seu artigo "Alimentos desde a concepção":

"É muito bonito falar em paternidade responsável, em proteção integral às crianças, porém é preciso dar efetividade a todos esses princípios. Certamente a responsabilidade é da Justiça. Para isso, não é necessário aguardar o legislador. Basta o Poder Judiciário continuar desempenhando o seu papel com coragem e responsabilidade, para garantir a todos o direito à dignidade humana, principalmente ao cidadão de amanhã."

Portanto, é por meio da conscientização acerca do assunto que será possível fazer valer o direito a alimentos gravídicos de forma efetiva. Afinal, autorizar o descumprimento de um determinado direito fundamental abre precedentes à inobservância de todos os demais. A manutenção da regra da lei significa o fortalecimento da sociedade civil e, em última instância, de todos os direitos inerentes à democracia.

Tanto a má aplicação do instituto dos alimentos gravídicos quanto a má-fé na propositura da ação pertinente não retiram a importância do direito a eles, o qual deve subsistir ainda que diante de resistências e controvérsias que se insurjam contra a sua efetivação.

\section{REFERÊNCIAS BIBLIOGRÁFICAS}

ALVES, Jones Figueirêdo. Alimentos do Ventre. Disponível em:

https://flaviotartuce.jusbrasil.com.br/artigos/150410520/alimentos-de-ventre-artigo-de-jonesfigueiredo-alves, 15-07-2017.

BERTOLIN, Patrícia Tuma Martins; ANDREUCCI, Ana Claudia Pompeu Torezan. Mulher, sociedade e direitos humanos. 1. ed. São Paulo: Rideel, 2010.

CAHALI, Yussef Said. Dos alimentos. 4. ed. São Paulo: Editora Revista dos Tribunais, 2002.

COELHO, Fábio Ulhoa. Curso de direito civil, família, sucessões. 5. ed. São Paulo: Saraiva, 2012.

DIAS, Maria Berenice. Manual de direito das famílias. 9. ed. São Paulo: Editora Revista dos Tribunais, 2013.

DIAS, Maria Berenice. Alimentos desde a concepção. Disponível em: http://www.mariaberenice.com.br/manager/arq/(cod2_528)12_alimentos_desde_a_concepcao.pdf, 15-07-2017. 
DIAS, Maria Berenice. Alimentos desde e até quando? Disponível em: http://www.mariaberenice.com.br/manager/arq/(cod2_536)4_alimentos_desde_e_ate_quando.pdf, 15-07-2017.

DIAS, Maria Berenice. Alimentos e paternidade responsável. Disponível em: http://www.mariaberenice.com.br/manager/arq/(cod2_515)25_alimentos_e_paternidade_responsave 1.pdf, 15-07-2017.

DIAS, Maria Berenice. Alimentos e presunção da necessidade. Disponível em: http://www.mariaberenice.com.br/manager/arq/(cod2_532)8_alimentos_e_presuncao_da_necessida de.pdf, 07-07-2017.

DIAS, Maria Berenice. Alimentos gravídicos? Disponível em: http://www.mariaberenice.com.br/manager/arq/(cod2_513)27_alimentos_gravidicos.pdf, 15-072017.

DIAS, Maria Berenice. Alimentos para a vida. Disponível em: http://www.mariaberenice.com.br/manager/arq/(cod2_512)28_alimentos_para_a_vida.pdf, 15-072017.

DIAS, Maria Berenice. Alimentos, ônus e encargos. Disponível em: http://www.mariaberenice.com.br/manager/arq/(cod2_534)6_alimentos_onus_e_encargos.pdf, 0707-2017.

DIAS, Maria Berenice. Dívida de alimento: um crédito de amor! Disponível em: http://www.mariaberenice.com.br/manager/arq/(cod2_535)5_divida_de_alimento_um_credito_de_a mor.pdf, 07-07-2017.

DIAS, Maria Berenice. Dois pesos e duas medidas para preservar a ética: irrepetibilidade e retroatividade do encargo alimentar. Disponível em: http://www.mariaberenice.com.br/manager/arq/(cod2_519)21_dois_pesos_e_duas_medidas_para_pr eservar_a_etica.pdf, 07-07-2017.

DIAS, Maria Berenice. Investigação de paternidade e alimentos desde a concepção. Disponível em: http://www.mariaberenice.com.br/manager/arq/(cod2_526)14_investigacao_de_paternidade_e_alim entos_desde_a_concepcao.pdf, 18-07-2017.

DIAS, Maria Berenice. Obrigação alimentar do Estado. Disponível em:

http://www.mariaberenice.com.br/manager/arq/(cod2_529)11_obrigacao_alimentar_do_estado.pdf , 07-07-2017.

DIAS, Maria Berenice. Princípio da proporcionalidade para além da coisa julgada. Disponível em: http://www.mariaberenice.com.br/manager/arq/(cod2_530)10_principio_da_proporcionalidade_para _alem_da_coisa_julgada.pdf , 07-07-2017.

DIAS, Maria Berenice. Termo inicial da obrigação alimentar na ação de alimentos e investigatória de paternidade. Disponível em:

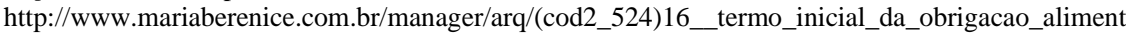
ar_na_acao_de_alimentos_e_na_investigatoria_de_paternidade.pdf, 18-07-2017. 
DIAS, Maria Berenice. Termo inicial da obrigação alimentar. Disponível em:

http://www.mariaberenice.com.br/manager/arq/(cod2_527)13_termo_inicial_da_obrigacao_aliment ar.pdf, 18-07-2017.

FREITAS, Douglas Phillips. Alimentos gravídicos e a Lei $n$. 11.804/08 - Primeiros reflexos.

Disponível em: http://www.migalhas.com.br/dePeso/16,MI73503,91041-

Alimentos+gravidicos+e+a+Lei+n+1180408+Primeiros+reflexos, 10-08-2017.

GONÇALVES, Carlos Roberto. Direito civil brasileiro, volume 6: direito de família. 9. ed. São

Paulo: Saraiva, 2012.

LOMEU, Leandro Soares. Alimentos Gravídicos Avoengos. Disponível em:

http://www.ambitojuridico.com.br/site/index.php?n_link=revista_artigos_leitura\&artigo_id=6117, 15-07-2017.

MADALENO, Rolf. A Presunção Relativa na Recusa à Perícia em DNA. Disponível em: http://www.rolfmadaleno.com.br/novosite/conteudo.php?id=44, 22-07-2017.

NERY JUNIOR, Nelson; NERY, Rosa Maria de Andrade. Código civil comentado. 10. ed. São Paulo: Editora Revista dos Tribunais, 2013.

NERY, Rosa Maria de Andrade. Manual de direito civil: família. 1. ed. São Paulo: Editora Revista dos Tribunais, 2013.

PEREIRA, Caio Mário da Silva. Instituições de direito civil. Atual. Tânia da Silva Pereira. 23. ed. Rio de Janeiro: Forense, 2015.

VENOSA, Sílvio de Salvo. Direito civil: direito de família. 13. ed. São Paulo: Atlas, 2013.

WAMBIER, Teresa Arruda Alvim; DIDIER JUNIOR, Fredie; TALAMINI, Eduardo; DANTAS, Bruno. Breves comentários ao Novo Código de Processo Civil. São Paulo: Editora Revista dos Tribunais, 2015. 